\title{
FUNGSI PELAKU DALAM KALIMAT PASIF BAHASA INDONESIA
}

\author{
Suher M. Saidi \\ Universitas Muhammadiyah Surabaya,SSuher_msaidi@yahoo.com
}

\begin{abstract}
Function actors in Indonesian passive sentences often escape discussion books Indonesian syntax. The discussion focused on the function of more active voice. Treatment of the passive voice is restricted to the existence of an active sentence. In some syntactic outstanding books in general, functions of the perpetrators not be discussed in a clear and detailed. The average of these books use the concept of the subject (actor) in the active sentence becomes the object (the perpetrator) if subjected to a passivating process. The purpose of this study demonstrate the concept of correct function in accordance with the rules of syntax Indonesian. This study uses descriptive qualitative reviewed the literature to examine the function of the perpetrator based on syntactic theories, especially theories on the book Raw Indonesian Grammar as the main reference book. In addition, other books about the theory of syntax also be literature studies. The results of this study describes that concept of the function of the sentence in the passive voice. The results of this study were 1) the function of the actors in the passive voice can serve as complementary actors, title, and description, 2) the object never appears in the passive voice
\end{abstract}

Key words: functionality, actors, passive sentences

\section{PENDAHULUAN}

Pembahasan kalimat pasif bahasa Indonesia tidak banyak kita jumpai pada bukubuku kajian bahasa Indonesia secara umum. Pembahasan lebih tercurahkan pada kalimat aktif. Baik fungsi maupun peran, kalimat aktif lebih banyak menjadi pokok pembicaraan. Mengapa pembahasan kalimat lebih banyak pada kalimat aktif?

Saat membahas kalimat pasif, selalu terkaitkan kalimat aktif. Seolah-olah pembentukan kalimat pasif harus berdasar pada kalimat kalimat aktif. Keberadaan kalimat pasif hanya merupakan efek atau akibat dari proses kebahasaan kalimat aktif.

Kalimat pasif merupakan kalimat yang muncul dari proses pemasifan kalimat aktif. Sugono (1994:86) menyatakan bahwa kalimat pasif adalah kalimat yang subjeknya sebagai sasaran perbuatan yang dinyatakan predikat. Kalimat tersebut merupakan kalimat ubahan dari kalimat pasif. 
Sebenarnya, jika kita kaji, kalimat pasif bisa kita kupas secara terpisah dari kalimat aktif. Memang, secara umum kalimat pasif yang sering muncul merupakan proses pemasifan. Namun, Pada beberapa konstruksi kalimat pasif tidak muncul karena proses pemasifan. Konstruksi-konstruksi tersebut seolah-olah terlupakan, terutama pada materi pembelajaran di sekolah.

Pada tulisan ini akan dikupas konstruksi kalimat pasif bahasa Indonesia. Penekanan kupasan terdapat pada fungsi peran pelaku dalam kalimat tersebut. Peran pelaku dan peran penderita/sasaran merupakan peran yang harus ada dalam proses kalimat aktif dan pasif. Peran pelaku wajib muncul dalam kalimat aktif, sedangkan peran penderita/sasaran keberadaannya wajib ada pada kalimat pasif.

Peran dan kewajiban muncul pada kalimat tersebut terlihat jelas jenis fungsinya dalam kalimat. Peran pelaku dalam kalimat aktif menduduki fungsi subjek. Peran penderita/sasaran dalam kalimat pasif juga menduduki subjek dalam kalimat. Bahkan, keberadaan peran tersebut menjadi pengertian kalimat aktif dan pasif. Putrayasa (2012: 91 dan 92) menjelaskan bahwa kalimat aktif adalah kalimat yang subjeknya melakukan pekerjaan, sedangkan kalimat pasif adalah kalimat yang subjeknya dikenai pekerjaan.

Bagimana dengan peran pelaku dalam kalimat pasif? Apa fungsi pelaku dalam kalimat pasif? Jawaban dari pertanyaan tersebut menjadi sebuah kajian yang menarik dalam analisis kebahasaan kalimat bahasa Indonesia. Perbedaan analisis terhadap jawaban pertanyaan tersebut terjadi pada beberapa buku sintaksis bahasa Indonesia.

Analisis fungsi pelaku dalam kalimat bahasa Indonesia adalah hal yang sangat perlu untuk dilakukan. Analisis ini bertujuan menunjukkan kaidah fungsi pada kalimat dengan tepat, terutama kalimat pasif. Selain itu, analisis ini bertujuan menambah khasanah keilmuan kebahasaindonesiaan.

Alasan lain, analisis ini perlu dilakukan karena ketidaktepatan konsep fungsi pelaku kalimat pasif bahasa Indonesia pada tataran materi di sekolah. Tampaknya, buku rujukan analisis tersebut kurang sesuai dengan rujukan buku Tata Bahasa Baku Bahasa Indonesia. Ketidaktepatan rujukan ini sudah mengakar sehingga hampir semua bukubuku sekolah yang mengupas masalah ini tidak sesuai dengan konsep yang tepat.

Kesalahan yang telah mengakar atau melembaga ini tentunya akan merusak kaidah pembelajaran bahasa Indonesia, terutama kajian tentang sintaksis. Apakah kesalahan-kesalahan tersebut harus kita biarkan? Tentunya, hal tersebut harus kita luruskan. Konsep-konsep yang sesuai dengan kaidah perlu diberikan 
Penelitian ini merupakan penelitian kualitatif deskriptif dengan telaah pustaka sebagai alat untuk mengupasnya. Mengapa pustaka sebagai alat untuk mengupas kajian ini? Permasalahan dalam kajian ini adalah telaah teori kebahasaan. Dengan demikian, telaah pustaka adalah pisau yang paling tepat dipakai.

Kenyataannya, pustaka-pustaka yang ditulis para linguis bahasa Indonesia sangatlah beragam. Banyak konsep ditawarkan . Mana yang tepat? Kita harus jeli menganalisisnya. Konsep-konsep tersebut memiliki dasar. Melalui tulisan ini akan kita kupas konsepkonsep yang sesuai kaidah. Konsep-konsep tentang fungsi pelaku dalam kalimat pasif secara benar sesuai kaidah.

\section{PEMBAHASAN}

Secara umum, pembahasan pelaku dalam kalimat pasif menduduki fungsi objek. Fungsi objek pada kalimat ini berasal dari ubahan kalimat aktif. Kalimat aktif memiliki peran pelaku sebagai subjek, peran penderita sebagai objek, dan verba aktif transitif sebagai predikat. Jika kalimat tersebut diubah menjadi pasif, yaitu imbuhan verba transitif mengmenjadi $d i$ - , fungsi kalimat tersebut akan berubah menjadi peran pelaku menjadi objek dan peran penderita menjadi subjek.

Berkaitan dengan hal tersebut, Chaer (2009:202) menjelaskan bahwa pembentukan kalimat pasif dari sebuah kalimat aktif dilakukan dengan cara 1) memindahkan objek kalimat aktif menjadi subjek dalam kalimat, 2) memindahkan subjek kalimat aktif menjadi objek kalimat pasif, dan 3) mengubah bentuk verba berprefiks meng- menjadi verba berprefiks $d i$ - . Proses tersebut dapat dibagankan seperti berikut. 


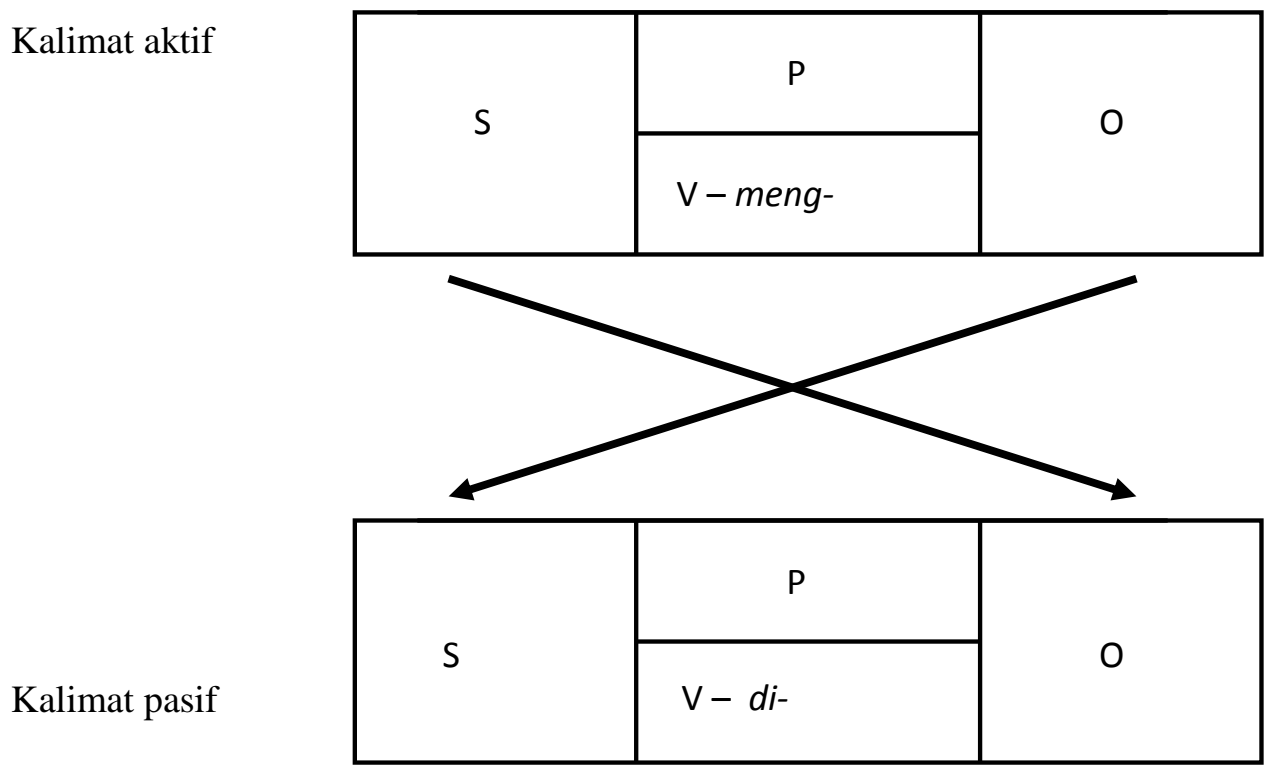

Peran pelaku dalam kalimat aktif berfungsi sebagai subjek. Jika diubah menjadi kalimat pasif, peran pelaku tersebut menjadi objek dalam kalimat. Peran penderita dalam kalimat aktif yang berfungsi sebagai objek akan berubah menjadi subjek dalam kalimat pasif.

Suparman dalam Putrayasa (2012:96) juga menegaskan hal yang sama dengan Chaer. Perhatikan tabel berikut!

\begin{tabular}{|l|l|l|l|}
\hline No. & $\begin{array}{l}\text { Unsur Kalimat aktif yang } \\
\text { diubah }\end{array}$ & $\begin{array}{l}\text { Berubah menjadi ... dalam } \\
\text { Kalimat Pasif }\end{array}$ & Keterangan \\
\hline 1. & Subjek pelaku & Objek pelaku & \\
\hline 2. & Kata kerja aktif & Kata kerja pasif & \\
\hline 3. & Objek penderita & Subjek penderita & \\
\hline 4. & Objek berkepentingan & Objek berkepentingan & Tidak berubah \\
\hline 5. & Adverbial & adverbial & Tidak berubah \\
\hline
\end{tabular}

Perhatikan contoh-contoh berikut!

(1a) Pejabat daerah menandatangani surat kesepakatan.

(1b) Surat kesepakatan ditandatangani pejabat daerah.

Kalimat (1a) memiliki konstituen pejabat daerah, konstituen menandatangani, dan konstituen surat kesepakatan. Konstituen pejabat daerah memiliki peran pelaku dan konstituen surat kesepakatan memiliki peran penderita/sasaran. Peran pelaku berfungsi 
sebagai subjek dan peran penderita/sasran berfungsi sebagai objek. Kalimat (1b) merupakan kalimat pemasifan dari kalimat (1a). Pada kalimat (1b) konstituen surat kesepakatan, yang sebelumnya dalam kalimat (1a) sebagai penderita/sasaran dan berfungsi objek, mengalami perubahan fungsi, yakni sebagai subjek, sedangkan konstituen pejabat daerah menjadi objek pelaku.

Berdasarkan contoh tersebut, pelaku dalam kalimat pasif berfungsi sebagai objek. Pertanyaannya, apakah pelaku harus sebagai objek dalam kalimat pasif? Yang perlu kita analisis adalah 1) ketepatan objek sebagai fungsi pelaku dalam kalimat pasif dan 2) fungsi-fungsi yang menduduki pada peran pelaku dalam kalimat pasif.

Menurut Alwi dkk. (2010:321), Kalimat minimal terdiri atas unsur predikat dan dan unsur subjek. Kedua unsur kalimat tersebut merupakan unsur yang kehadirannya selalu wajib. Keberadaan objek, pelengkap, dan keterangan bersifat bebas bergantung kebutuhan kalimat tersebut.

Arifin (2009: 55) menegaskan bahwa kalimat dasar adalah kalimat yang terdiri atas unsur-unsur pokok. Kalimat dasar adalah kalimat yang belum mendapat perluasan. Paling kurang kalimat dasar terdiri atas unsur subjek dan unsur predikat. Kalimat dasar yang agak panjang terdiri atas unsur subjek, predikat, dan objek. Artinya, unsur objek bisa wajib muncul karena tuntutan predikat kalimat. Kalimat yang berpredikat aktif transitif menghendaki kehadiran unsur objek dalam kalimat.

Mari kita analisis tentang objek dalam kalimat! Menurut Sugono (1994:53), objek hanya terdapat dalam kalimat aktif transitif. Kalimat aktif transitif adalah kalimat aktif yang predikatnya merupakan verba aktif transitif. Alwi dkk. (2010:335) juga menyatakan bahwa objek adalah konstituen kalimat yang kehadirannya dituntut oleh predikat yang berupa verba transitif pada kalimat aktif. Letaknya selalu setelah langsung predikatnya.

Perhatikan contoh-contoh kalimat berikut!

(2) Pemerintah melaksanakan program keluarga berencana..

(3) Mobil tua itu mengangkut potongan besi.

(4) Beberapa bank telah memberikan kemudahan kredit.

(5) Remindra memperdalam ilmu filsafat di universitas terkemuka.

(6) Uang itu telah dikirim Pak Hamid.

(7) Program kepariwisataan sedang digalakkan Pemerintah.

(8) Harga BBM diturunkan Presiden pekan ini.

(9) Kebijakan itu disambut baik masyarakat Indonesia. 
Kalimat (2 - 5) merupakan kalimat aktif, sedangkan kalimat (6 - 9) merupakan kalimat pasif. Pada kalimat $(2-5)$ kata pemerintah, mobil tua, beberapa bank, dan Remindra memiliki peran sebagai pelaku. Kata-kata tersebut menempati fungsi sebagai subjek kalimat. Kata program keluarga berencana, potongan besi, kemudahan kredit, dan ilmu filsafat memiliki peran sebagai penderita/sasaran. Kata-kata tersebut menempati fungsi sebagai objek kalimat.

Jika kita lihat menurut kaidah munculnya objek, kata-kata yang berperan sebagai penderita/sasran tersebut berterima sebagai fungsi objek kalimat. Mari kita analisis!

(2a) Pemerintah melaksanakan.

(3a) Mobil tua itu mengangkut.

(4a) Beberapa bank telah memberikan.

(5a) Remindra telah memperdalam.

Jika peran penderita/sasaran dalam kalimat aktif tersebut ditiadakan, kalimat tersebut menjadi kalimat yang tidak berterima. Secara gramatikal kalimat tersebut memenuhi syarat, yaitu memiliki subjek dan predikat. Namun, secara semantis kalimat tersebut belum final karena keutuhan maksud kalimat belum tuntas. Dengan demikian peran penderita/sasaran dalam kalimat (2 - 5) berfungsi sebagai objek karena keberadaannya dituntut hadir oleh predikat kalimat, yaitu verba transitif.

Bagaimana dengan peran pelaku dalam kalimat pasif? Apakah peran pelaku dalam kalimat pasif juga berfungsi sebagai objek kalimat? Perhatikan analisis berikut!

(6) a. Uang itu telah dikirim Pak Hamid

b. Uang itu telah dikirim.

(7) a. Program kepariwisataan sedang digalakkan Pemerintah.

b. Program kepariwisataan sedang digalakkan.

(8) a. Harga BBM diturunkan Presiden pekan ini.

b. Harga BBM diturunkan.

(9) a. Kebijakan itu disambut baik masyarakat Indonesia.

b. Kebijakan itu disambut baik.

Kalimat (6 - 9), baik secara gramatikal maupun semantis, merupakan kalimat yang berterima. Kalimat (6b) Uang itu telah dikirim memiliki fungsi subjek dan predikat. Uang itu merupakan subjek kalimat dan telah dikirim merupakan predikat. Kalimat tersebut tidak memerlukan konstituen lain agar menjadi kalimat yang berterima. Kalimat tersebut mampu berdiri sendiri sebagai kesatuan kalimat. Secara semantis pun kalimat 
tersebut sudah final. Jika kalimat tersebut mendapat tambahan, konstituen tambahan tersebut hanya bersifat melengkapi.

Kalimat (7b, 8b, dan 9b) juga sama dengan kalimat (6b). Artinya, keberadaan konstituen Pak Hamid, Pemerintah, Presiden, dan masyarakat Indonesia bisa dihilangkan. Ketidakberadaan konstituen tersebut tidak mengurangi keberterimaan kalimat-kalimat tersebut. Dengan demikian, fungsi objek pada peran pelaku kalimat (6 9) tidaklah tepat. Jika konstituen tersebut merupakan objek, keberadaannya harus ada sehingga tidak dapat dihilangkan. Konstituen tersebut wajib muncul karena tuntutan dari predikat yang menghendaki keberadaannya.

Apakah fungsi pelaku pada kalimat pasif tersebut? Mungkinkah pelengkap atau keterangan yang menduduki fungsi pelaku dalam kalimat pasif tersebut? Untuk menjawab pertanyaan tersebut, harus kita pahami terlebih dulu tentang fungsi keterangan dan pelengkap dalam kalimat. Kita harus memahami ciri-ciri keterangan dan pelengkap.

Fungsi keterangan menurut Sugono (1994:59) adalah unsur kalimat yang memberikan informasi lebih lanjut tentang suatu yang dinyatakan dalam kalimat. Fungsi keterangan merupakan unsur tambahan (periferal) yang kehadirannya dalam struktur dasar tidak bersifat wajib.

Masih menurut Sugono, ciri-ciri penting keterangan adalah 1) bukan unsur utama dan 2) tidak terikat posisi. Fungsi keterangan dalam suatu kalimat bersifat manasuka. Karena bukan merupakan unsur utama, keterangan boleh muncul boleh tidak. Selain itu, keterangan tidak terikat posisi. Keberadaannya bisa di depan, di tengah, atau di belakang. Karena sifatnya tidak terikat posisi, keterangan dapat dimutasi keberadaannya.

Perhatikan contoh kalimat berikut!
a. Arya menonton pertunjukan musik di Surabaya.
b. Di Surabaya Arya menonton pertunjukan musik
c. Arya di Surabaya menonton pertunjukan musik.

Fungsi keterangan dalam kalimat tersebut, yaitu konstituen di Surabaya dapat dimutasi ke berbagai posisi. Permutasian fungsi keterangan tersebut tidak mengubah makna kalimat tersebut.

Apakah peran pelaku dalam kalimat $(6$ - 9) tersebut berfungsi sebagai keterangan?

Perhatikan kalimat berikut!

(6) a. Uang itu telah dikirim Pak Hamid. 
b. Pak Hamid uang itu telah dikirim.

c. Uang itu Pak Hamid telah dikirim.

a. Program kepariwisataan sedang digalakkan Pemerintah.

b. Pemerintah program kepariwisataan sedang digalakkan.

c. Program kepariwisataan Pemerintah sedang digalakkan.

(8) a. Harga BBM diturunkan Presiden pekan ini.

b. Presiden harga BBM diturunkan pekan ini.

c. Harga BBM Presiden diturunkan pekan ini.

(9) a. Kebijakan itu disambut baik masyarakat Indonesia.

b. Masyarakat Indonesia kebijakan itu disambut baik.

c. Kebijakan itu masyarakat Indonesia disambut baik.

Konstituen Pak Hamid, Pemerintah, Presiden, dan masyarakat Indonesia merupakan pelaku-pelaku dalam kalimat (6 - 9) tersebut. Jika kita cermati, konstituenkonstituen tersebut tidak bisa berpindah tempat. Kalimat bagian (a) saja merupakan kalimat yang berterima. Kalimat bagian (b dan c) menjadi kalimat yang tidak jelas secara semantisnya.

Maksud kalimat (6a), Uang itu telah dikirim Pak Hamid, sangat jelas. Terdapat tindakan dalam kalimat tersebut, yaitu dikirim. Sesuatu yang dikirim adalah uang itu. Pelaku pengiriman adalah Pak Hamid. Kita bandingkan kalimat (6a) dengan kalimat (6b dan 6c). Pada kalimat (6b dan 6c) konstituen Pak Hamid tidak jelas fungsinya. Kalimat (6b), Pak Hamid uang itu telah dikirim, tidak memiliki makna yang jelas. Permutasian konstituen Pak Hamid di awal dan di tengah kalimat membuat semantis kalimat tersebut tidak berterima.

Bagaimana kalimat (7 - 9)? Kalimat tersebut tidak berbeda dengan kalimat (6b dan $6 c)$. Pada kalimat (7b,7c,8b,8c,9b, dan 9c) tersebut konstituen pelaku tidak memiliki fungsi secara jelas. Kalimat-kalimat tersebut, baik secara gramatikal maupun semantis, tidak berterima. Berdasarkan analisis tersebut, dapat kita simpulkan bahwa peran pelaku dalam kalimat pasif tersebut tidak berfungsi sebagai keterangan. Sesuai ciri keterangan, pelaku dalam kalimat pasif tersebut tidak dapat digolongkan ke dalamnya.

Jika peran pelaku dalam kalimat tersebut tidak berfungsi sebagai objek dan keterangan, apakah pelaku tersebut berfungsi sebagai pelengkap? Fungsi dalam kalimat adalah subjek, predikat, objek, keterangan, dan pelengkap. Peran pelaku dalam kalimat pasif tersebut kemungkinan menduduki fungsi objek, keterangan, atau pelengkap. Jika peran pelaku kalimat tersebut tidak menduduki fungsi objek dan keterangan, fungsi 216 | E-ISSN: 2527-8754 http:// journal.unesa.ac.id/index.php/Paramasastra 
pelengkap menjadi satu-satunya alternatif ditempati peran pelaku dalam kalimat tersebut. Namun, mari kita analisis terlebih dahulu hal tersebut sebelum memutuskannya.

Alwi dkk. (2010:336) menyatakan bahwa pengertian pelengkap sering dicampuradukkan dengan pengertian objek. Hal tersebut dapat dimaklumi karena kedua konsep tersebut terdapat kemiripan. Baik pelengkap maupun objek sering berwujud nomina dan keduanya sering menduduki tempat yang sama, yaitu di belakang verba.

Perbedaan yang sangat mencolok antara keberadaan objek dengan pelengkap adalah predikat yang muncul dalam kalimat tersebut. Predikat pada kalimat yang berobjek merupakan verba tansitif, sedangkan predikat pada kalimat yang berpelengkap adalah verba intransitif. Kedua verba tersebut merupakan verba aktif.

Perhatikan contoh kalimat berikut!

(11) a. Andika mempelajari ilmu agama di pesantren.

b. Andika belajar ilmu agama di pesantren.

Konstituen ilmu agama pada kalimat (10a) berfungsi sebagai objek. Konstituen ilmu agama pada kalimat (10b) merupakan pelengkap karena verba pada predikatnya adalah verba intransitif. Pada kedua contoh tersebut tampak bahwa konstituen ilmu agama adalah frasa nominal dan berdiri langsung di belakang verba mempelajari dan belajar. Pada (11a) jika kalimat tersebut dipasifkan, konstituen ilmu agama akan menduduki fungsi subjek pada kalimat pasif. Namun, Kalimat (11b) tidak dapat dipasifkan sehingga konstituen ilmu agama bukan berfungsi sebagai objek, melainkan sebagai pelengkap.

Bagaimana hal tersebut jika terjadi pada kalimat pasif? Pada buku-buku sintaksis tidak pernah terbahas pelengkap pada kalimat pasif. Pembahasan pelengkap selalu terfokus pada kalimat aktif. Perbedaan fungsi pelengkap dan objek hanya terjadi pada kalimat aktif.

Mari kita analisis fungsi pelengkap pada kalimat pasif. Alwi dkk. (2010:353) menyatakan secara implisit bahwa pelengkap pelaku hadir dalam kalimat pasif berasal dari subjek kalimat aktif (yang sebelumnya subjek kalimat aktif).

Perhatikan kalimat (6 - 9) berikut!

(6) Uang itu telah dikirim Pak Hamid.

(7) Program kepariwisataan sedang digalakkan Pemerintah.

(8) Harga BBM diturunkan Presiden pekan ini.

(9) Kebijakan itu disambut baik masyarakat Indonesia. 
Konstituen Pak Hamid, Pemerintah, Presiden, dan masyrakat Indonesia merupakan pelaku dalam kalimat tersebut. Konstituen tersebut merupakan subjek pada kalimat sebelum pemasifan. Dengan demikian, ketika kalimat tersebut dipasifkan, konstituen tersebut berfungsi sebagai pelengkap seperti yang Alwi dkk. jelaskan. Jika kalimat tersebut diuraikan menurut fungsinya, fungsi kalimat tersebut sebagai berikut.

(6) Uang itu telah dikirim Pak Hamid.

$\begin{array}{lll}S & P & \text { Pel }\end{array}$

(7) Program kepariwisataan sedang digalakkan Pemerintah.

P Pel

(8) Harga BBM diturunkan Presiden pekan ini.

$\begin{array}{llll}S & P & \text { Pel } & K\end{array}$

(9) Kebijakan itu disambut baik masyarakat Indonesia.

$\begin{array}{lll}\mathrm{S} & \mathrm{P} & \mathrm{Pel}\end{array}$

Senada dengan Alwi dkk., Kridalaksana dalam Putrayasa (2014:68) menyatakan bahwa pelengkap pelaku, bagian klausa berupa nomina atau frasa nominal, yang melengkapi verba pasif dan secara semantik merupakan pelaku. Hal tersebut terlihat seperti Raminra dalam Buku itu dibaca Raminra. Dengan demikian, peran pelaku dalam kalimat pasif tipe seperti tersebut menduduki fungsi sebagai pelengkap.

Putrayasa sendiri dalam bukunya Analisis Kalimat: Fungsi, Kategori, dan Peran terlihat tidak konsisten. Putrayasa mengambil pendapat dari Kridalaksana, yaitu pelaku dalam kalimat pasif berfungsi sebagai pelengkap. Namun, dalam bukunya, Putrayasa (2014:66) menuliskan bahwa pelaku dalam kalimat pasif berfungsi sebagai objek. Kalimat yang dicontohkan adalah Ruangan saya (S) dibersihkan (P) oleh pembantu (O).

Kalimat pasif yang teranalisis tersebut hanya merupakan salah satu tipe kalimat pasif yang memiliki konstituen sebagai pelaku dalam kalimat. Berikut akan kita bahas kalimat-kalimat pasif yang memiliki konstituen sebagai pelaku dalam kalimat.

Perhatikan kalimat-kalimat berikut ini!

Tipe 1.

(1) Kertas itu dipotong adikku

Tipe 2

(2) Tarif tol diturunkan oleh Menteri Perhubungan.

Tipe 3

(3) Kakekku dibawakan baju baju oleh Kakak.

218 | E-ISSN: 2527-8754 http:// journal.unesa.ac.id/index.php/Paramasastra 
Tipe 4

(4) Masalah itu telah aku bicarakan tadi pagi.

Tipe 5

(5) Kaki adikku terinjak pengunjung kemarin malam.

Tipe 6

(6) Temanku kena bujuk wanita itu.

Kalimat pasif tipe 1 telah kita bahas sebelumnya. Pembahasan dengan berbagai teori dari linguis telah menghasilkan paparan-paparan tentang fungsi pelaku kalimat pasif. Pelaku dalam kalimat pasif tipe 1, konstituen adikku, berfungsi sebagai pelengkap. Alwi dkk. menyebutnya pelengkap pelaku.

Kalimat pasif tipe 2 merupakan kalimat yang hampir sama dengan dengan kalimat pasif tipe 1 . Perbedaannya terletak pada preposisi dalam tipe 2 sebelum peran pelaku. Preposisi oleh mendahului konstituen Menteri Perhubungan sebagai pelaku dalam kalimat pasif tersebut.

Menurut Alwi dkk. (2010:337), Konstituen keterangan biasanya berupa frasa nominal, frasa preposisi, atau frasa adverbial. Frasa preposisi secara umum menjadi fungsi keterangan dalam kalimat, baik kalimat aktif maupun pasif. Memang, pada kasus tertentu frasa preposisi bisa sebagai predikat. Ciri keterangan adalah permutasian. Konstituen yang menduduki fungsi keterangan dapat bermutasi ke tempat lain. Perhatikan kalimat berikut!

(2) Tarif tol diturunkan oleh Menteri Perhubungan.

a. Oleh Menteri Perhubungan tariff tol diturunkan.

b. Tarif tol oleh Menteri Perhubungan diturunkan.

Preposisi oleh membuat konstituen tersebut lebih leluasa berpindah tempat. Karena kemampuan untuk bermutasi atau berpindah tempat, konstituen tersebut, pelaku dalam kalimat, berfungsi sebagai keterangan. Beberapa buku menegaskan bahwa preposisi oleh pada kalimat pasif bersifat manasuka. Sebuah bentuk yang dimunculkan pasti memiliki maksud. Tidak mungkin sesuatu muncul tanpa ada maksud dan peran dalam kalimat.

Kalimat pasif tipe 3 muncul dari pemasifan bentuk aktif. Jika kalimat pasif tipe 1 dan 2 berasal dari pemasifan verba transitif, Kalimat pasif tipe 3 muncul dari pemasifan 
verba dwitansitif. Kalimat pasif tipe 3 pada contoh tersebut berasal dari kalimat aktif Kakak membawakan kakek baju baru. Kalimat tersebut memiliki fungsi sebagai berikut.

(3) a. Kakak membawakan kakek baju baru.

$\begin{array}{llll}\mathrm{S} & \mathrm{P} & \mathrm{O} & \mathrm{Pel}\end{array}$

Alwi dkk. (2010:349) menyatakan bahwa terdapat verba transitif dalam bahasa Indonesia yang secara semantis mengungkapkan hubungan tiga maujud. Dalam bentuk aktif, maujud itu masing-masing merupakan subjek, objek, dan pelengkap. Verba itu dinamakan verba dwitransitif.

Kalimat aktif dengan verba dwitransitif memiliki makna suatu pekerjaan untuk orang lain. Makna seperti tersebut dinamakan makna benefaktif. Semua kalimat yang beverba dwitransitif selalu bermakna benefaktif. Makna benefaktif dalam verba tersebut menuntut munculnya fungsi objek dan pelengkap. Jika dipasifkan, kalimat aktif tersebut akan berubah sebagai berikut.

(3) Kakek dibawakan baju baru oleh Kakak.

Pelaku dalam kalimat pasif tipe 3 tersebut adalah konstituen oleh Kakak. Sama halnya dengan kalimat pasif tipe 2, konstituen tersebut menduduki fungsi keterangan. Konstituen oleh Kakak memiliki kemampuan bermutasi dalam kalimat. Kemampuan tersebut menyebabkan konstituen oleh Kakak berfungsi sebagai keterangan. Secara lengkap fungsi kalimat tersebut adalah Kakek (S) dibawakan (P) baju baru(Pel) oleh $\operatorname{Kakak}($ Ket).

Kalimat pasif tipe 4 juga merupakan kalimat hasif pemasifan kalimat aktif. Kalimat pasif yang berasal dari kalimat aktif dengan peran pelaku pronominal persona (kata ganti orang) pertama, kedua, dan ketiga mempunyai bentuk yang berbeda dengan tipe 1 - 3. Kalimat pasif tipe 4 tersebut disebut kalimat pasif persona. Kalimat pasif persona adalah kalimat pasif yang predikatnya pelaku dalam kegiatan. Predikat kalimat ini tersusun aspek + pelaku + verba imperatif.

Perhatikan kalimat berikut!

(4) a. Aku telah membicarakan masalah itu tadi pagi.

$\begin{array}{llll}S & P & O & K\end{array}$

b. Masalah itu telah aku bicarakan tadi pagi.

$\begin{array}{lll}\mathrm{S} & \mathrm{P} & \mathrm{K}\end{array}$

c. Aku akan membaca buku itu sore nanti.

$\begin{array}{llll}S & P & O & K\end{array}$

d. Buku itu akan aku baca sore nanti. 
S $\mathrm{P} \quad \mathrm{K}$

e. Anda belum membayar biaya pengobatan di klinik ini.

$\begin{array}{llll}\mathrm{S} & \mathrm{P} & \mathrm{O} & \mathrm{K}\end{array}$

f. Biaya pengobatan belum Anda bayar di klinik ini.

$\mathrm{P}$

$\mathrm{P}$

$\mathrm{K}$

Pada contoh kalimat tersebut terdapat tiga kalimat aktif dan tiga kalimat pasif. Kalimat aktif terdapat pada kalimat (4a, 4c, dan 4e), sedangkan kalimat pasif terdapat pada kalimat (4b, 4d, dan 4f). Pemasifan kalimat aktif tersebut tidak mengubah verba transitif berafiks meng- menjadi di-, tetapi afiks meng- menjadi verba imperatif. Susunan predikatnya adalah aspek + pelaku + verba imperatif. Aspek dalam predikat tersebut bisa dimunculkan dan bisa ditiadakan sesuai kebutuhan dan kepentingan kalimat.

Kekeliruan sering terjadi pada predikat kalimat pasif tipe 4 tersebut. Susunan predikatnya tidak aspek + pelaku + verba imperatif, tetapi pelaku + aspek + verba imperatif. Kalimat pemasifannya tidak menjadi Masalah itu telah aku bicarakan, tetapi menjadi Masalah itu aku telah bicarakan. Pemasifan tersebut tidak berterima.

Peran pelaku dalam kalimat pasif tipe 4 ini berfungsi sebagai predikat dalam kalimat. Kalimat (4b, 4d, 4f) memiliki pelaku sebagai predikat dalam kalimat pasif. Selain itu, kalimat tipe ini tidak memiliki objek dan pelengkap dalam kalimat. Konstituen kalimat pasif ini hanya subjek, predikat, dan keterangan yang tidak bersifat wajib.

Selain bentuk kalimat pasif tipe 1 - 4, Sugono (1994:90) menyatakan bahwa ada sejumlah kalimat pasif yang ditandai oleh predikat verba pasif berprefiks ter-. Kalimatkalimat yang berpredikat verba berprefiks ter- memperlihatkan bahwa subjek dikenani (sasaran) perbuatan yang dinyatakan predikat dan mempunyai makna tidak disngaja. Pada kalimat pasif tipe 5, yaitu berpredikat verba berprefiks ter-, pelaku muncul setelah posisi predikat. Walaupun tidak melakukan perbuatan secara langsung, konstituen tersebut tetap sebagai pelaku.

Perhatikan kalimat berikut!

(5) Kaki adikku terinjak pengunjung kemarin malam.

Konstituen kaki adikku merupakan sasaran dari predikat terinjak. Konstituen pengunjung bukan merupakan konstituen yang harus ada karena predikat sehingga konstituen tersebut bukan merupakan objek. Selain itu, konstituen tersebut tidak dapat bermutasi. Konstituen pengunjung merupakan pelengkap pada kalimat pasif tersebut. 
Secara lengkap fungsi kalimat tersebut adalah Kaki adikku (S) terinjak (P) pengunjung (Pel) tadi malam (K).

Kalimat pasif tipe 6 adalah kalimat pasif yang hampir tidak pernah dibahas dalam buku-buku sintaksis. Beberapa buku sintaksis karangan AbdulChaer, Ida Bagus Putrayasa, Sakura Ridwan, dan Ramlan tidak sedikit pun menyinggung kalimat pasif tipe 6 ini. Kalimat tipe ini kita jumpai pada buku Berbahasa Indonesia dengan Benar karangan Dendy Sugono.

Sugono (1994) menyatakan bahwa kalimat pasif juga dalam pengertian tidak sengaja ditandai oleh kata kena.

(6) a. Temanku kena bujuk wanita itu.

b. Telapak kakinya kena tusuk duri.

c. Adikku kena pukul temanku.

Kalimat pasif tipe 6 ini memang jarang dipergunakan. Konstituen kena bujuk, kena tusuk, dan kena pukul diganti dengan terbujuk, tertusuk, dan terpukul. Tidak semua kata kena $+\ldots$ dapat digantikan dengan kata ter $+\ldots$. Kata kena pukul memiliki makna tidak sengaja. Jika kata kena pukul diganti kata terpukul, terjadi perbedaan makna. Kata terpukul bisa bermakna telah dipukul.

Konstituen wanita itu, duri, dan temanku memiliki peran sebagai pelaku. Walaupun tidak secara langsung melakukan tindakan, tetapi nomina tersebut sebagai pelaku yang mengenai sasaran. Peran pelaku tersebut berkategori sebagai nomina yang berada langsung setelah predikat. Pelaku tersebut juga tidak mungkin sebagai objek dan tidak memiliki kemampuan untuk bermutasi. Berdasarkan ciri tersebut, fungsi pelaku dalam kalimat-kalimat pasif tersebut adalah sebagai pelengkap.

Sebenarnya masih terdapat bentuk kalimat pasif bahasa Indonesia. Namun, bentuk tersebut tidak kami bahas dalam tulisan ini. Bentuk-bentuk kalimat pasif yang tidak kami bahas dikarenakan dalam kalimat pasif tersebut tidak memiliki peran pelaku

\section{SIMPULAN}

Kalimat pasif bahasa Indonesia tidak semuanya berasal dari pemasifan kalimat aktif. Secara umum, kalimat pasif yang dipakai dalam kegiatan berbahasa adalah kalimat hasil pemasifan kalimat aktif. Namun, beberapa kalimat pasif juga bisa muncul tidak karena proses pemasifan. 
Peran pelaku dalam kalimat pasif menduduki beragam fungsi kalimat. Terdapat enam tipe kalimat pasif berpelaku. Tipe-tipe kalimat pasif tersebut beserta fungsinya tertera sebagai berikut.

(1) Kertas itu dipotong adikku.

$$
\text { S P Pel }
$$

(2) Tarif tol diturunkan oleh Menteri Perhubungan.

S

$\mathrm{P}$

$\mathrm{K}$

(3) Kakekku dibawakan baju baju oleh Kakak.

$\begin{array}{llll}\mathrm{S} & \mathrm{P} & \mathrm{K} & \mathrm{K}\end{array}$

(4) Masalah itu telah aku bicarakan tadi pagi. $\mathrm{S}$

$\mathrm{P}$

$\mathrm{K}$

(5) Kaki adikku terinjak pengunjung kemarin malam.

S

$\mathrm{P}$

Pel

K

(6) Temanku kena bujuk wanita itu.

S

$\mathrm{P}$

Pel

Peran pelaku dalam kalimat pasif tipe $1-6$ tersebut adalah adikku, oleh Menteri Perhubungan. Oleh Kakak, aku, pengunjung, dan wanita itu. Pelaku pada kalimat pasif tipe 1, adikku, menduduki fungsi pelengkap (Pel). Pelaku kalimat pasif tipe 2, oleh Menteri Perhubungan, menduduki fungsi keterangan (K). Pelaku kalimat pasif tipe 3, oleh Kakak, menduduki fungsi keterangan (K). Pelaku kalimat pasif tipe 4 , aku dalam telah aku bicarakan, menduduki fungsi predikat $(\mathrm{P})$. Pelaku kalimat pasif tipe 5 dan 6 , pengunjung dan wanita itu, menduduki fungsi pelengkap (Pel).

Berdasarkan hal tersebut, pelaku dalam kalimat pasif dapat berfungsi sebagai predikat (P), pelengkap (Pel), dan keterangan (Ket). Pelaku dalam kalimat pasif tidak pernah menduduki fungsi subjek dan objek. Subjek dalam kalimat pasif selalu diisi peran penderita/sasaran.

\section{DAFTAR RUJUKAN}

Alwi, Hasan dkk. 2010. Tata Bahasa Baku Bahasa Indonesia. Jakarta : Balai Pustaka.

Arifin, E. Zaenal dan Junaiyah. 2009. Sintaksis. Jakarta : PT Grasindo.

Chaer, Abdul. 2009. Sintaksis Bahasa Indonesia (Pendekatan Proses). Jakarta : PT Rineka Cipta.

http:// journal.unesa.ac.id/index.php/Paramasastra E-ISSN: 2527-8754 | 223 
Putrayasa, Ida Bagus. 2012. Jenis Kalimat dalam Bahasa Indonesia. Bandung : PT Refika Aditama . 2014. Analisis Kalimat : Fungsi, Kategori, dan Peran. Bandung : PT Refika Aditama.

Sugono, Dendy. 1994. Berbahasa Indonesia dengan Benar. Jakarta : Puspa Swara. 